\title{
Ru Catalysts Supported on Commercial and Biomass-Derived Activated Carbons for the Transformation of Levulinic Acid into $\gamma$-Valerolactone under Mild Conditions
}

\author{
Zaira Ruiz-Bernal, María Ángeles Lillo-Ródenas (D) and María del Carmen Román-Martínez *(D)
}

check for

updates

Citation: Ruiz-Bernal, Z.;

Lillo-Ródenas, M.Á.;

Román-Martínez, M.d.C. Ru

Catalysts Supported on Commercial

and Biomass-Derived Activated

Carbons for the Transformation of

Levulinic Acid into $\gamma$-Valerolactone

under Mild Conditions. Catalysts

2021, 11, 559. https://doi.org/

$10.3390 /$ catal11050559

Academic Editor: Maria A. Goula

Received: 23 March 2021

Accepted: 26 April 2021

Published: 28 April 2021

Publisher's Note: MDPI stays neutral with regard to jurisdictional claims in published maps and institutional affiliations.

Copyright: (c) 2021 by the authors. Licensee MDPI, Basel, Switzerland. This article is an open access article distributed under the terms and conditions of the Creative Commons Attribution (CC BY) license (https:/ / creativecommons.org/licenses/by/ $4.0 /)$.
MCMA Group, Department of Inorganic Chemistry and Materials Institute (IUMA), Faculty of Sciences, University of Alicante, Ap. 99, E-03080 Alicante, Spain; zaira.ruiz@ua.es (Z.R.-B.); mlillo@ua.es (M.Á.L.-R.)

* Correspondence: mcroman@ua.es; Tel.: +34-965903975

Abstract: Ru catalysts (1 wt.\%) supported on commercial and biomass-derived activated carbons (AC) have been prepared, thoroughly characterized, and used in the hydrogenation of levulinic acid to produce gamma-valerolactone (GVL). This is an important platform compound that plays a key role in the production of liquid fuels and that can also be used, for example, as a food flavoring agent, antifreeze, and solvent. The study focuses on the influence of the carbon support characteristics, such as porous texture and acidity, on the properties and performance (LA conversion and selectivity to GVL) of the catalysts. Catalytic activity tests have been carried out at $170{ }^{\circ} \mathrm{C}$ and also in noticeably milder conditions $\left(70^{\circ} \mathrm{C}\right)$ to implement a less energy-demanding process. All the catalysts show high LA conversion and GVL yield at $170{ }^{\circ} \mathrm{C}$, while at $70^{\circ} \mathrm{C}$, important differences between them, related to the support properties, have been found. The catalysts prepared with more acidic supports show better catalytic properties: very good catalytic performance ( $98 \%$ LA conversion and $77 \%$ selectivity to GVL) has been obtained in mild temperature conditions.

Keywords: carbon materials; ruthenium; levulinic acid; gamma-valerolactone; lignocellulosic biomass; hydrogenation; catalytic activity

\section{Introduction}

The massive use of fossil fuels has led to their depletion and to important environmental pollution problems. To face this situation, it is necessary to promote the use of renewable energy sources and to develop both new strategies for energy production and sustainable methods to obtain chemical products. In this line, lignocellulosic biomass residues are renewable raw materials with the potential to produce high added-value products [1,2], such as fuels, platform molecules for the chemical industry, and functional materials [3]. The main sources of lignocellulosic biomass are agricultural and forestry residues.

Lignocellulosic biomass is composed of hemicellulose (15-30 wt.\%), cellulose (30-50 wt.\%), and lignin (15-30 wt.\%), in proportions that depend on the biomass nature and with different reactivity and transformation possibilities (Figure 1). The hydrolysis of cellulose produces glucose, which can be further hydrolyzed to 5-hydroxymethylfurfural (HMF), an interesting precursor for the synthesis of other high added-value chemicals, and leads to the formation of levulinic acid (LA) and formic acid (FA) [4,5] by rehydration. Levulinic acid can be also obtained from xylose, the hydrolysis product of hemicellulose, after dehydration to furfural and hydrogenation to furfuryl alcohol (Figure 1). LA is one of the best chemical platform compounds, leading to suitable intermediates for the preparation of a variety of pharmaceutical and industrial products with applications, such as food flavoring agents, antifreeze, solvents, etc. [6-10]. Among the interesting products that can be obtained from LA, gamma-valerolactone (GVL) stands out because it is a relevant compound in a "cascade" of processes for the production of liquid fuels and also because it has important direct applications, for example, as a fragrance, food ingredient, fuel 
additive, and solvent. Some of these applications are related to interesting properties, such as limited reactivity with water or oxygen, high boiling point, low vapor pressure, and low toxicity [11-13]. GVL can be obtained from levulinic acid by any of the two routes shown in Figure 2 [14]: (i) dehydration to produce the intermediate angelica lactone (AL), which is further hydrogenated, or (ii) hydrogenation, to produce 4-hydroxypentanoic acid (HPA) by reduction of the carbonyl group, followed by dehydration.

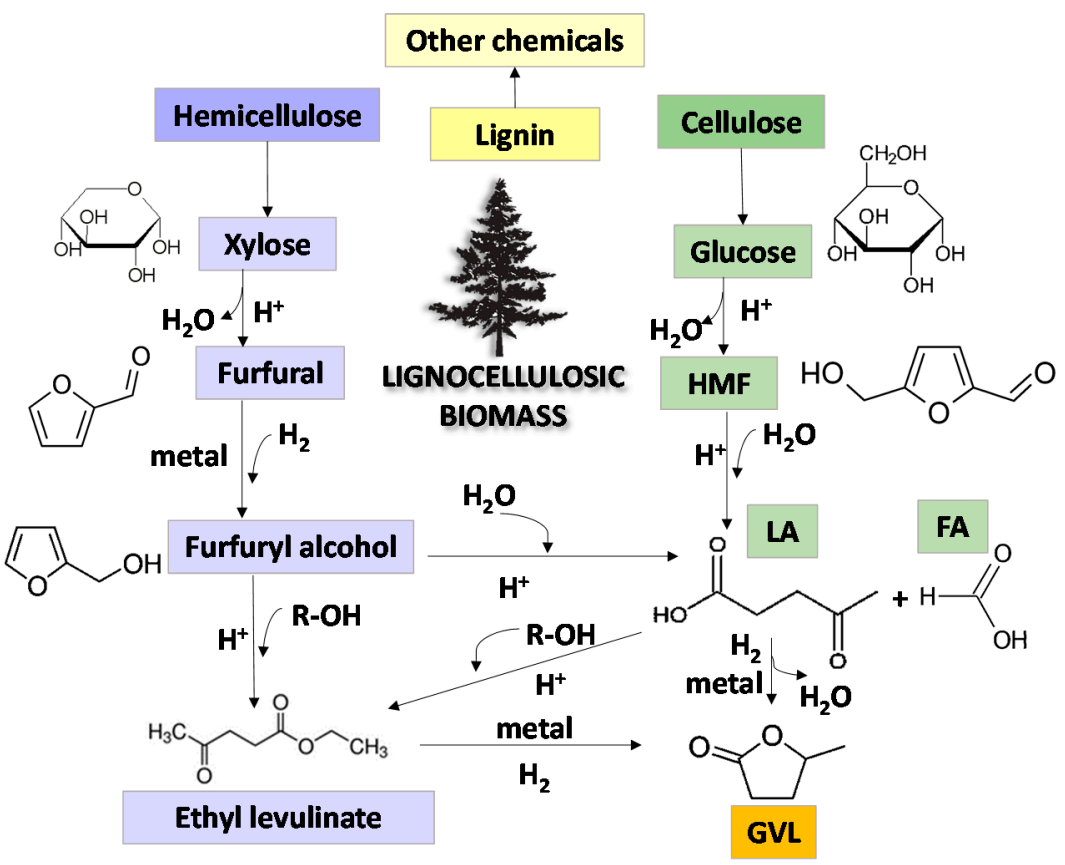

Figure 1. Degradation routes of lignocellulosic biomass, adapted from [5].

The process requires the use of a catalyst and severe pressure and temperature conditions to achieve a high GVL yield [15]. Regarding the catalytic system, it must be active for the hydrogenation of carbonyl groups, but some acidity is also required for the dehydration step.

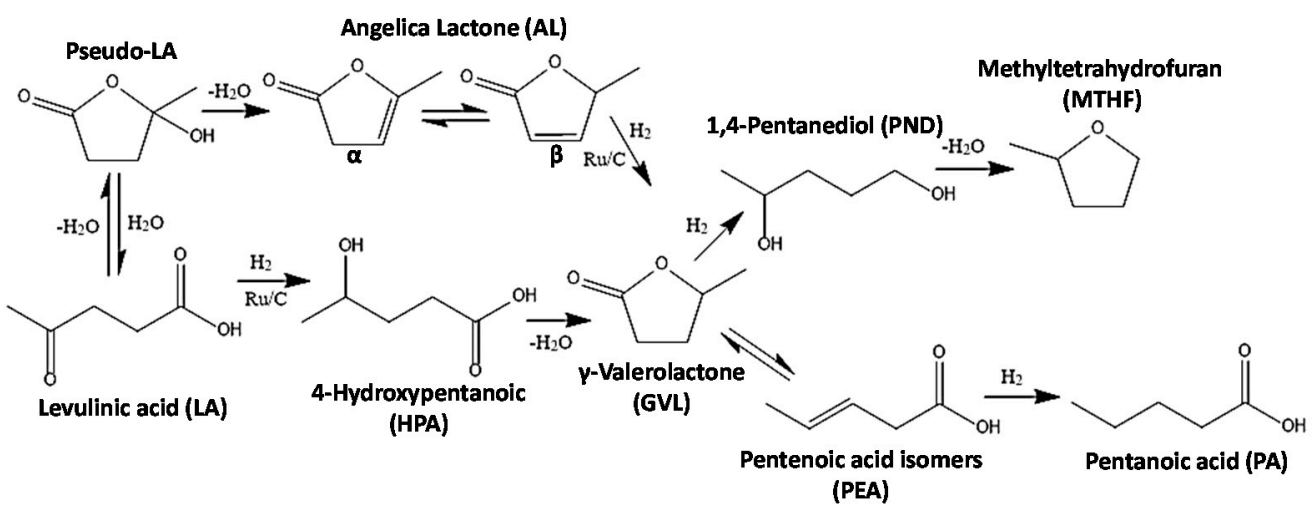

Figure 2. Scheme of potential reactions taking place in the hydrogenation of levulinic acid to obtain $\gamma$-valerolactone, based on schemes in $[14,16]$.

Hydrogenation of LA to obtain GVL has been carried out with both homogenous and heterogeneous catalysts [12]. In reference to homogenous systems, Starodubtseva et al. [17] reported the effectivity of a $\mathrm{Ru}^{\mathrm{II}}-\mathrm{BINAP}-\mathrm{HCl}$ catalytic system, with $95 \%$ GVL yield in ethanol, and Mehdi et al. [18] reported a 96\% GLV yield using Ru(acac) 3 -TPPTS in a water solution. However, homogeneous systems have limitations, such as difficult recoverability 
and lower thermal stability, hindering their use on an industrial scale. Because of that, heterogeneous catalysts are the most promising and technically feasible option. A current challenge is to reduce the energy demand of the process by using more efficient (active and selective) catalysts and milder reaction conditions.

Many authors have claimed that supported noble metal catalysts show good performance in the conversion of LA to GVL, among which ruthenium-based ones present the highest catalytic activity and selectivity $[12,14,15,19-21]$. The ruthenium-supported catalysts have proved to be efficient in many other reactions, highlighting, as an example, their performance in hydrogenation reactions $[14,22,23]$. The support plays a relevant role, as it allows a good dispersion of the hydrogenation active species and regulates the degree of metal-support interaction, which has been reported to influence the catalytic activity $[24,25]$. Besides, it must also be responsible for the acidic character of the catalysts, being an active species as well.

Several materials have been reported as supports for $\mathrm{Ru}$ and other noble metals in the development of catalysts for the transformation of LA into GVL. Some examples are inorganic oxides like $\mathrm{SiO}_{2}$ [26], $\mathrm{ZrO}_{2}$ [27], and $\mathrm{TiO}_{2}$ [28], polymeric materials as cross-linked sulfonated polyethersulfone (SPES) [29], materials of mineral origin like hydroxyapatite (HPA) [30], and carbon materials [21]. Among them, carbon materials can be considered an interesting option, due to their tunable surface area and porous structure, surface chemistry, and the possibility of being shaped in different morphologies [24]. Moreover, as they can be obtained from lignocellulosic biomass residues, the use of this kind of carbon materials to prepare catalysts for LA hydrogenation would contribute to an integral approach towards the valorization of the mentioned residues. From a broad perspective, they can be regarded as a suitable alternative to prepare green catalysts.

There are a number of publications dealing with $\mathrm{Ru} / \mathrm{C}$ catalysts $[19,24,25,31,32]$. However, in most of them, the obtained catalytic activity results are not discussed in relation to the support physicochemical properties. Moreover, although interesting results have been already obtained with carbon-supported Ru catalysts, it is still a challenge to develop a catalytic system with high efficiency (high GVL yield) achieved in as mild as possible conditions (mainly, low temperature, low pressure, short reaction time, low metal content, and water as a solvent).

Thus, the purpose of this work is to develop carbon-supported Ru catalysts that fulfill the aforementioned requirements, optimizing as much as possible the resources. Catalysts with a low Ru content, $1 \mathrm{wt} . \%$, have been prepared using different carbon materials as supports. They have been characterized in detail and tested in the LA hydrogenation to GVL both in regular and mild reaction conditions. The study focuses on the influence of the supports' characteristics (porous structure, surface area, and surface chemistry), on the catalysts' properties and catalytic behavior.

\section{Results and Discussion}

\subsection{Textural Properties of Supports and Catalysts}

Figure 3 shows the $\mathrm{N}_{2}$ adsorption-desorption isotherms obtained for the supports and the reduced $\mathrm{Ru}^{\mathrm{R}} / \mathrm{C}$ catalysts. The isotherms are type IV according to IUPAC classification [33], typical of materials that contain both micro and mesopores. 


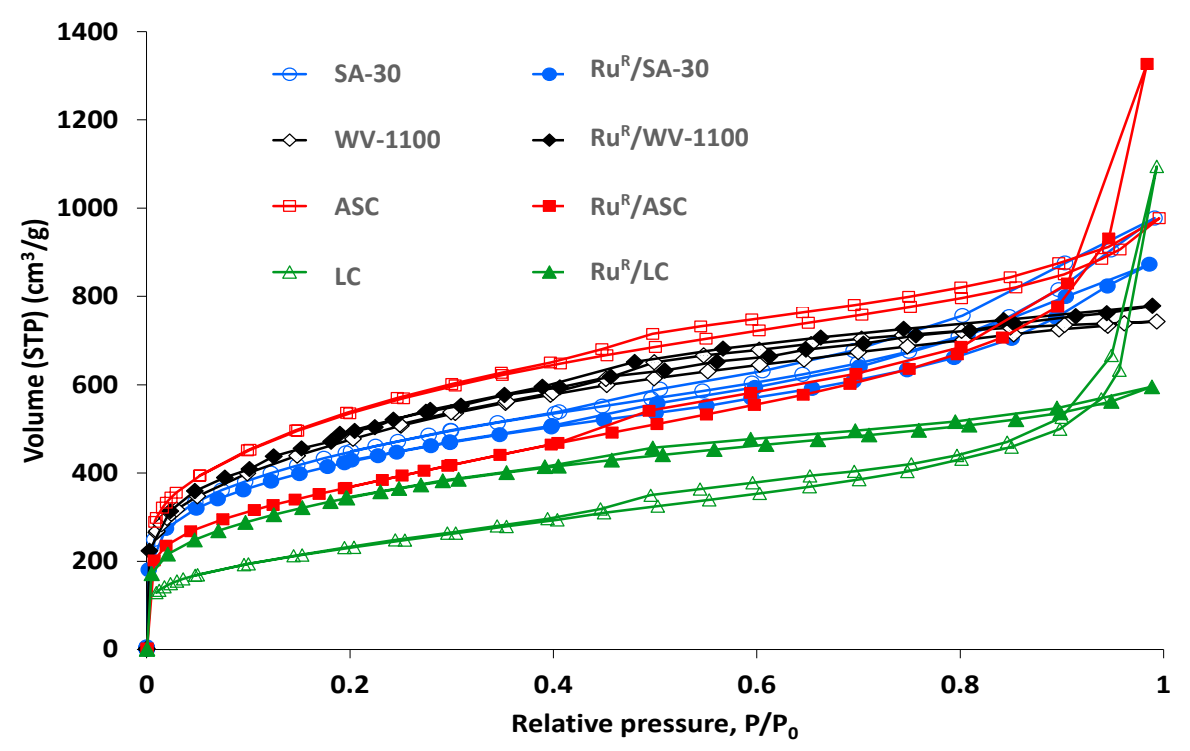

Figure 3. $\mathrm{N}_{2}$ adsorption-desorption isotherms at $-196{ }^{\circ} \mathrm{C}$ for the carbon supports and the reduced catalysts.

The calculated values of specific surface area and pore volumes for supports and catalysts (as prepared and reduced) are presented in Table 1.

Table 1. Textural properties of carbon supports and catalysts (as prepared and reduced).

\begin{tabular}{|c|c|c|c|c|c|c|}
\hline Sample & $\begin{array}{c}S_{\text {BET }} \\
\left(\mathrm{m}^{2} / g\right)\end{array}$ & $\begin{array}{l}V_{D R, N 2} \\
\left(\mathrm{~cm}^{3} / \mathrm{g}\right)\end{array}$ & $\begin{array}{c}V_{\text {meso }} \\
\left(\mathrm{cm}^{3} / \mathrm{g}\right)\end{array}$ & $\begin{array}{c}V_{T} \\
\left(\mathrm{~cm}^{3} / \mathrm{g}\right)\end{array}$ & $\begin{array}{c}\mathrm{V}_{\mathrm{DR}, \mathrm{CO} 2} \\
\left(\mathrm{~cm}^{3} / \mathrm{g}\right)\end{array}$ & $\begin{array}{c}\mathrm{V}_{\text {super micro }} \\
\left(\mathrm{cm}^{3} / \mathrm{g}\right)\end{array}$ \\
\hline SA-30 & 1587 & 0.68 & 0.57 & 1.51 & 0.35 & 0.33 \\
\hline $\mathrm{Ru} / \mathrm{SA}-30$ & 1465 & 0.63 & 0.51 & 1.36 & 0.33 & 0.30 \\
\hline $\mathrm{Ru}^{\mathrm{R}} / \mathrm{SA}-30$ & 1505 & 0.64 & 0.51 & 1.35 & 0.31 & 0.33 \\
\hline WV-1100 & 1713 & 0.70 & 0.38 & 1.15 & 0.37 & 0.33 \\
\hline $\mathrm{Ru} / \mathrm{WV}-1100$ & 1671 & 0.68 & 0.39 & 1.16 & 0.38 & 0.30 \\
\hline $\mathrm{Ru}^{\mathrm{R}} / \mathrm{WV}-1100$ & 1771 & 0.73 & 0.40 & 1.20 & 0.38 & 0.35 \\
\hline ASC & 1916 & 0.79 & 0.49 & 1.51 & 0.43 & 0.36 \\
\hline $\mathrm{Ru} / \mathrm{ASC}$ & 1918 & 0.79 & 0.49 & 1.50 & 0.43 & 0.36 \\
\hline $\mathrm{Ru}^{\mathrm{R}} / \mathrm{ASC}$ & 1323 & 0.55 & 0.60 & 1.44 & 0.27 & 0.28 \\
\hline LC & 831 & 0.33 & 0.41 & 0.98 & 0.19 & 0.12 \\
\hline $\mathrm{Ru} / \mathrm{LC}$ & 761 & 0.30 & 0.39 & 0.95 & 0.17 & 0.13 \\
\hline $\mathrm{Ru}^{\mathrm{R}} / \mathrm{LC}$ & 1238 & 0.51 & 0.30 & 0.92 & 0.17 & 0.34 \\
\hline
\end{tabular}

Data in Table 1 show that the carbon materials used in this work have significantly different textural properties, regarding both surface area and pore size distribution.

After impregnation with the $\mathrm{RuCl}_{3}$ aqueous solution and drying, the samples show, in general, a small decrease in their adsorption capacity with respect to the corresponding carbon supports. However, after the reduction treatment there is a noticeable increase in the surface area of sample $\mathrm{Ru}^{\mathrm{R}} / \mathrm{LC}$ (a very slight increase is also found for $\mathrm{Ru}^{\mathrm{R}} / \mathrm{WV}$ ). Data in Table 1 show that the surface area increase in sample $\mathrm{Ru}^{\mathrm{R}} / \mathrm{LC}$ is related to a significant increase in the micro and supermicropore volumes. It seems that part of this porosity of the LC carbon was blocked and it has been cleared upon the catalyst reduction heat treatment. Such treatment, in pure $\mathrm{H}_{2}$ at $250^{\circ} \mathrm{C}$ for $4 \mathrm{~h}$, probably removes oxygen functional groups (OFG), leaving some pores accessible to gas adsorption. The process of OFG removal could be catalyzed by the reduced Ru species. Thus, as it will be shown in the next paragraph, the TPD profiles of the reduced catalysts are different from those of the pristine supports (Table S1 and Figure S1). These differences can be related to modifications associated to the impregnation step, but also to a catalytic effect of metallic Ru to decompose OFG. Data of Table $\mathrm{S} 1$ show that the amount of $\mathrm{CO}_{2}$ and $\mathrm{CO}$ evolved increases for all the reduced 
catalysts compared to the supports, but such an increase is particularly high in the case of sample $\mathrm{Ru}^{\mathrm{R}} / \mathrm{LC}$. This means that in this case, the surface chemistry (and likely also the textural properties) of the LC carbon is more prone to thermally induced modifications, in particular, those catalyzed by the Ru nanoparticles.

A thorough analysis comparing the different pore volumes (Table 1) in supports and reduced catalysts shows that, in general, and due to the low $\mathrm{Ru}$ loading, the supported $\mathrm{Ru}$ nanoparticles have a relatively slight effect on the porosity. However, such an effect is not equal for the different catalysts and allows to draw an approximate image of the location of the Ru particles within the porosity. Figure $\mathrm{S} 2$ shows a graphic of such a comparison. Thus, for sample $\mathrm{Ru}^{\mathrm{R}}$ /SA-30, there is only a small decrease of the micropore volume $\left(\mathrm{V}_{\mathrm{DR}, \mathrm{N} 2}\right.$, and $\mathrm{V}_{\mathrm{DR}, \mathrm{CO} 2}$ ); for $\mathrm{Ru}^{\mathrm{R}} / \mathrm{WV}-1100$, the pore volume does not decrease at all; in the case of $\mathrm{Ru}^{\mathrm{R}} / \mathrm{ASC}$, there is a significant decrease of the micropore volume $\left(\mathrm{V}_{\mathrm{DR}}, \mathrm{N} 2, \mathrm{~V}_{\mathrm{DR}}, \mathrm{CO} 2\right.$, and $\mathrm{V}_{\text {super micro }}$ ) and in the case of $\mathrm{Ru}^{\mathrm{R}} / \mathrm{LC}$, the decrease is noticeable in the mesopore volume, although, as commented, the micropore volume also increases, due to OFG removal.

\subsection{Surface Chemistry of Supports and Catalysts}

Figure 4 shows the $\mathrm{CO}_{2}$ and $\mathrm{CO}$ evolution TPD curves obtained for the carbon supports. $\mathrm{CO}_{2}$ and $\mathrm{CO}$ evolve as a consequence of the decomposition of oxygen functional groups (OFG) with different thermal stability and different chemical nature [34-37]. $\mathrm{CO}_{2}$ is mainly generated by the decomposition of functional groups with acidic character like carboxylic acids, anhydrides, and lactones, that decompose in the following temperature intervals: $\sim 230-380^{\circ} \mathrm{C}, \sim 520-550^{\circ} \mathrm{C}$, and $\sim 650-670{ }^{\circ} \mathrm{C}$, respectively. On the other hand, $\mathrm{CO}$ emission is due to the decomposition of weakly acidic phenol type groups, and carbonyls and quinones, with basic character, that decompose at higher temperatures: at $\sim 650-700$ ${ }^{\circ} \mathrm{C}$ and $\sim 750-943{ }^{\circ} \mathrm{C}$, respectively.

(a)

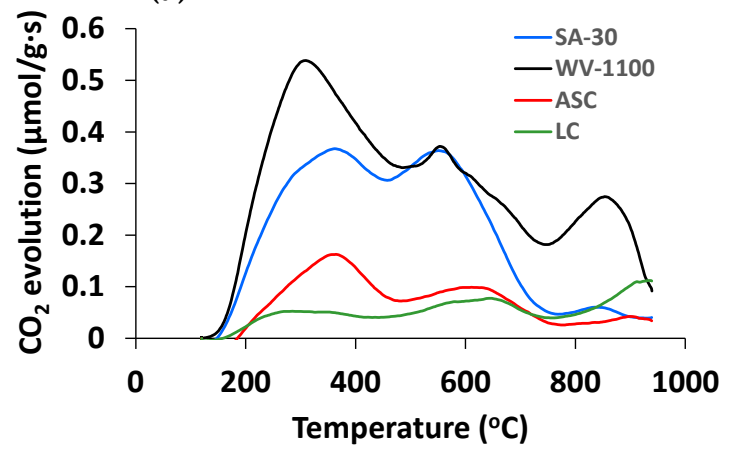

(b)

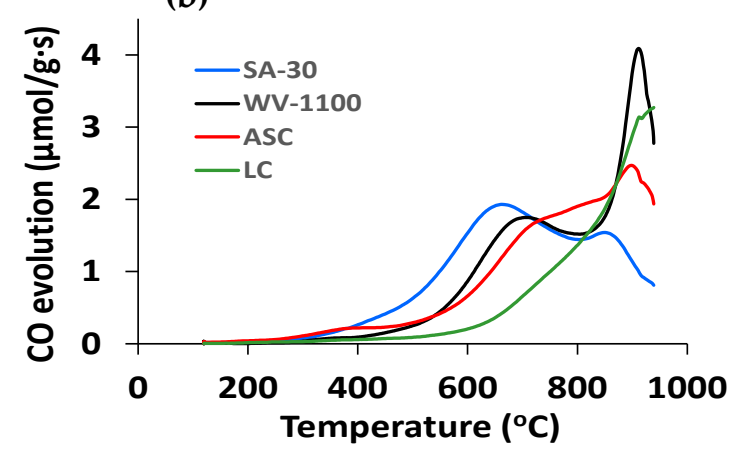

Figure 4. TPD spectra of carbon supports: (a) $\mathrm{CO}_{2}$ evolution and (b) $\mathrm{CO}$ evolution (be aware of the different scales in the $\mathrm{y}$-axis in figures $(\mathbf{a}, \mathbf{b}))$.

Besides, $\mathrm{CO}$ and, especially, $\mathrm{CO}_{2}$ desorption at high temperature, above $\sim 860{ }^{\circ} \mathrm{C}$ (Figure 4) is not common and can be explained by the decomposition of OFG related to the presence of residual phosphorus species remaining from the $\mathrm{H}_{3} \mathrm{PO}_{4}$ activation treatment. As previously reported, $\mathrm{C}-\mathrm{O}-\mathrm{P}$ bonds present on the surface are thermally unstable at temperatures above $700{ }^{\circ} \mathrm{C}[38,39]$.

The quantification of the TPD profiles of the carbon supports is presented in Table 2. These data reveal important differences in the surface chemistry of the supports: biomassderived ACs have a lower amount of surface oxygen groups, and lower $\mathrm{CO}_{2} / \mathrm{CO}$ ratio, than commercial ones, which can be linked to a higher basic character of the former ones. 
Table 2. Amount of $\mathrm{CO}_{2}$ and $\mathrm{CO}$ from TPD experiments, $\mathrm{CO}_{2} / \mathrm{CO}$ molar ratio and calculated total oxygen content in the carbon supports.

\begin{tabular}{ccccc}
\hline Sample & $\mathbf{C O}_{\mathbf{2}}(\boldsymbol{\mu \mathrm { mol } / \mathrm { g } )}$ & $\mathbf{C O}(\mu \mathrm{mol} / \mathrm{g})$ & $\mathbf{C O}_{\mathbf{2}} / \mathbf{C O}$ & $\mathbf{O}_{\text {total }}$ (wt.\%) \\
\hline SA-30 & 539 & 2065 & 0.26 & 5.0 \\
WV-1100 & 735 & 2203 & 0.33 & 5.9 \\
ASC & 276 & 2024 & 0.14 & 4.1 \\
LC & 146 & 1455 & 0.10 & 2.8 \\
\hline
\end{tabular}

The reduced catalysts have been also characterized by TPD experiments. As mentioned above, the TPD profiles of the reduced catalysts are significantly different from those of the pristine supports (Table S1 and Figure S1) as a consequence of modifications of the OFG associated with the impregnation step and the influence of the presence of metallic $\mathrm{Ru}$ in their thermal decomposition $[40,41]$. The amounts of generated $\mathrm{CO}_{2}$ and $\mathrm{CO}$, products of the OFG decomposition, are higher for the reduced catalysts than for the supports and reflects that with the aid of the Ru nanoparticles more OFG can be decomposed in the temperature interval used in the TPD experiments. The mentioned increment of decomposed OFG depends on the nature of the carbon material and has shown to be the highest for sample $\mathrm{Ru}^{\mathrm{R}} / \mathrm{LC}$.

\subsection{TEM and XPS Analysis of Ru Catalysts}

Figure 5 shows some representative TEM images of the $\mathrm{Ru}^{\mathrm{R}} / \mathrm{C}$ catalysts. It can be observed that the four samples contain small Ru nanoparticles. The particle size distribution determined from the measurement of more than 100 particles (see Figure S3 and Table S2) reveals that the average particle size is around $2 \mathrm{~nm}$ in the four catalysts. The observed particles are very well distributed in the $\mathrm{Ru}^{\mathrm{R}} / \mathrm{ASC}$ catalyst, whereas in the other three catalysts they seem to be concentrated in particular regions. Besides, for the $\mathrm{Ru}^{\mathrm{R}} / \mathrm{SA}$ 30 catalyst some larger particles have also been observed (see inset of Figure S3). These differences imply that the support properties affect the interaction of the Ru precursor with the support's surface and, likely, also the modifications occurring during the reduction process.

(a)

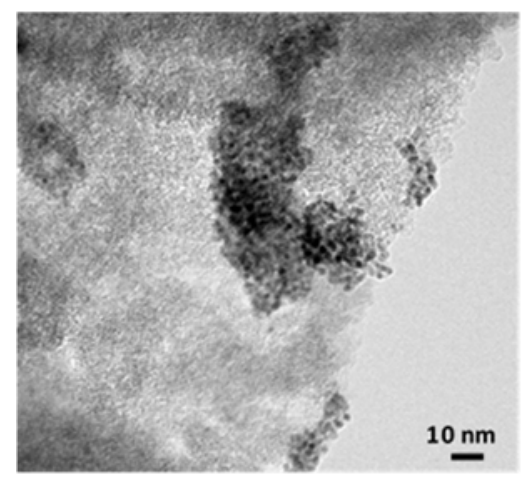

(b)

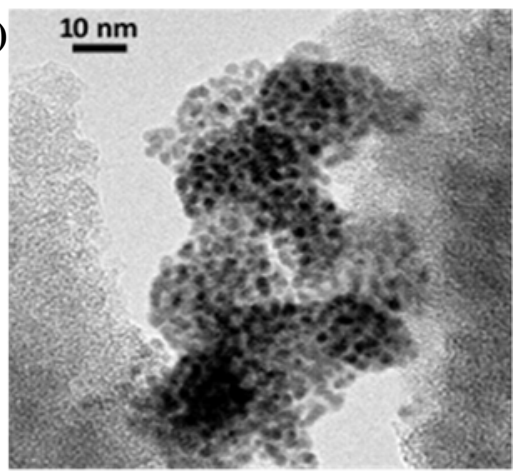

Figure 5. Cont. 
(c)

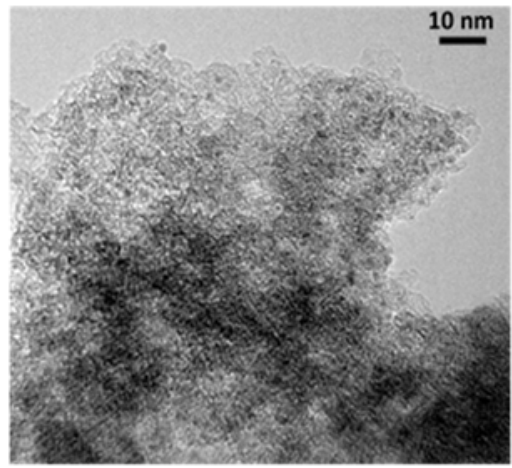

(d)

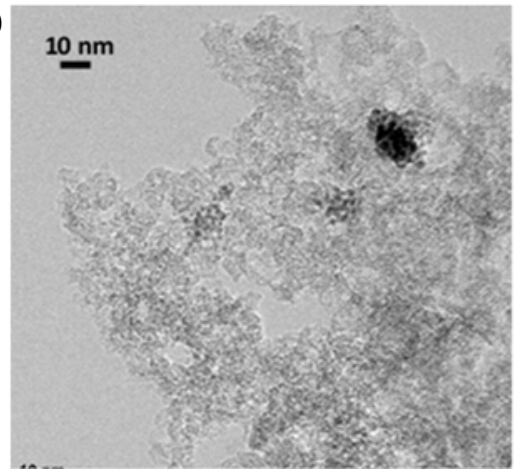

Figure 5. TEM images of reduced catalysts: (a) $\mathrm{Ru}^{\mathrm{R}} / \mathrm{SA}-30$, (b) $\mathrm{Ru}^{\mathrm{R}} / \mathrm{WV}-1100$, (c) $\mathrm{Ru}^{\mathrm{R}} / \mathrm{ASC}$ and (d) $\mathrm{Ru}^{\mathrm{R}} / \mathrm{LC}$.

Figure 6 shows the $\mathrm{Ru} 3 \mathrm{p}_{3 / 2}$ XPS spectra of the $\mathrm{Ru}^{\mathrm{R}} / \mathrm{C}$ catalysts. Two Ru species with different $3 p_{3 / 2}$ binding energy (B.E.) are present in these samples: $\mathrm{Ru}^{0}$ (B.E. of about $462 \mathrm{eV}$ ) [42] and $\mathrm{RuO}_{\mathrm{x}} / \mathrm{Ru}^{0}$ ( $\mathrm{Ru}$ oxide on metallic $\mathrm{Ru}$, with B.E. of about $465 \mathrm{eV}$ ) [43]. The presence of $\mathrm{RuCl}_{3}$ can be discarded because the reported B.E. for this species is $464.1 \mathrm{eV}$ [44]. The B.E. values, the atomic percentage of the two mentioned species, and the atomic $\mathrm{Ru} / \mathrm{C}$, $\mathrm{Cl} / \mathrm{C}$, and $\mathrm{Cl} / \mathrm{Ru}$ ratios are presented in Table $3 . \mathrm{Ru}^{0}$ is the predominant species in the four catalysts (more than 60 at.\%). The presence of $\mathrm{Ru}$ as $\mathrm{RuO}_{\mathrm{x}} / \mathrm{Ru}^{0}$ means that partial surface oxidation of the Ru particles takes place upon exposure to the environment. It can be pointed out that the proportion of $\mathrm{Ru}^{0}$ is the largest (83 at.\%) in the $\mathrm{Ru}^{\mathrm{R}} / \mathrm{WV}-1100$ catalyst, meaning that the reduced Ru particles are more stable in this sample. However, there is not a clear relationship between this observation and the carbon support properties.

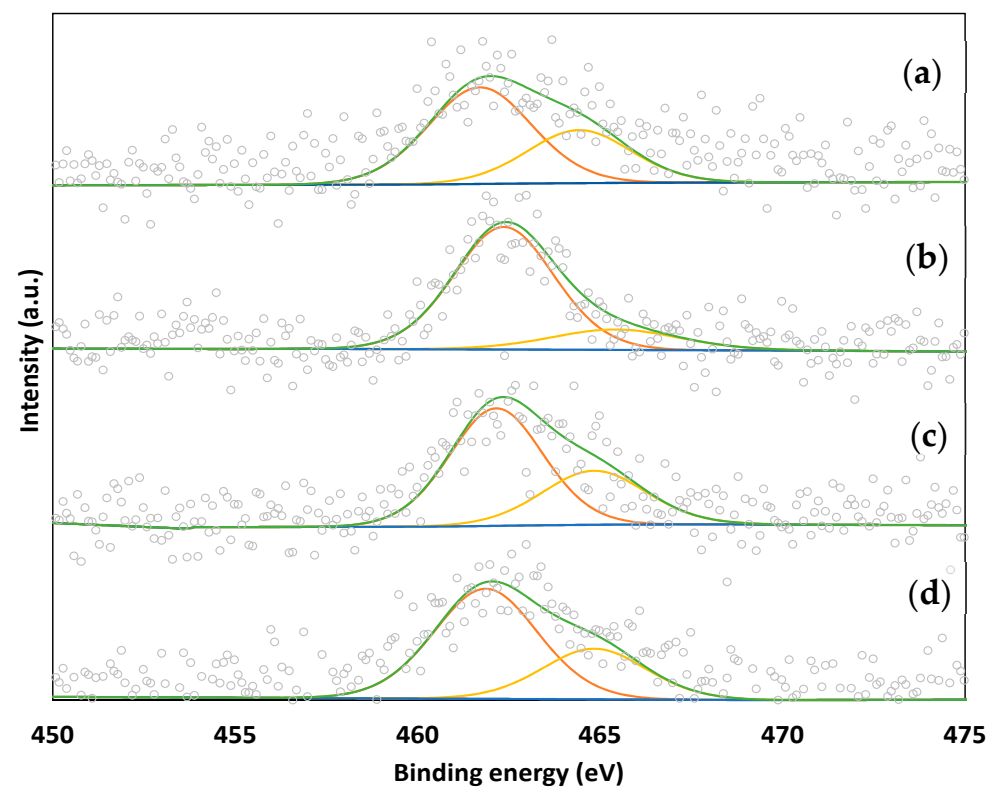

Figure 6. Ru $3 p_{3 / 2}$ XPS spectra of (a) $\mathrm{Ru}^{\mathrm{R}} / \mathrm{SA}-30$, (b) $\mathrm{Ru}^{\mathrm{R}} / \mathrm{WV}-1100$, (c) $\mathrm{Ru}^{\mathrm{R}} / \mathrm{ASC}$ and (d) $\mathrm{Ru}^{\mathrm{R}} / \mathrm{LC}$. 
Table 3. $\mathrm{Ru} 3 \mathrm{p}_{3 / 2}$ XPS data: B.E (eV), atomic percentages, and relevant atomic ratios.

\begin{tabular}{|c|c|c|c|c|c|}
\hline \multirow{2}{*}{ Sample } & \multicolumn{2}{|c|}{$R u 3 p_{3 / 2}$ B.E. $(e V)$} & \multirow[b]{2}{*}{$\mathrm{Ru} / \mathrm{C}$} & \multicolumn{2}{|c|}{ Atomic Ratio } \\
\hline & $\mathbf{R} \mathbf{u}^{\mathbf{0}}$ & $\mathrm{RuO}_{\mathbf{x}} / \mathbf{R u}^{0}$ & & $\mathrm{Cl} / \mathrm{C}$ & $\mathrm{Cl} / \mathrm{Ru}$ \\
\hline $\mathrm{Ru}^{\mathrm{R}} / \mathrm{SA}-30$ & $461.70(63 \%)$ & $464.42(37 \%)$ & 0.0026 & 0.0005 & 0.19 \\
\hline $\mathrm{Ru}^{\mathrm{R}} / \mathrm{WV}-1100$ & $462.36(83 \%)$ & $465.42(17 \%)$ & 0.0032 & 0.0032 & 1.00 \\
\hline $\mathrm{Ru}^{\mathrm{R}} / \mathrm{ASC}$ & $462.15(66 \%)$ & $464.83(34 \%)$ & 0.0032 & 0.0035 & 1.10 \\
\hline $\mathrm{Ru}^{\mathrm{R}} / \mathrm{LC}$ & $461.87(68 \%)$ & $464.84(32 \%)$ & 0.0031 & 0.0011 & 0.36 \\
\hline
\end{tabular}

The slight differences in the $\mathrm{Ru} 3 \mathrm{p}_{3 / 2}$ B.E. values corresponding to $\mathrm{Ru}^{0}$ and $\mathrm{RuO}_{x} / \mathrm{Ru}^{0}$ in the different catalysts are not significant. The standard deviation is 0.25 and 0.35 , respectively—values which are well in the reported intervals for these data [44] —and can be associated with fitting difficulties, due to the lower intensity signal arising from the low $\mathrm{Ru}$ loaded catalysts.

The $\mathrm{Ru} / \mathrm{C}$ atomic ratio is very similar for the four catalysts, meaning that the $\mathrm{Ru}$ dispersion is similar, in agreement with the similitude of the $\mathrm{Ru}$ particle size determined from the TEM analysis. Small amounts of chlorine ( 0.1-0.9 wt.\%) and phosphor $(\sim 1.5-2 \mathrm{wt} . \%)$ have been detected to be present in the catalysts. According to the $\mathrm{Cl} / \mathrm{Ru}$ ratio, the $\mathrm{Ru}^{\mathrm{R}} / \mathrm{WV}-1100$ and $\mathrm{Ru}^{\mathrm{R}} / \mathrm{ASC}$ catalysts keep about $1 / 3$ of the chlorine from the impregnation process. Some chloride commonly remains in catalysts prepared by a similar preparation method and conditions, as evidenced in other works as [24,30,45,46].

\subsection{Catalytic Activity Tests}

Blank experiments (without catalyst) do not show LA conversion. However, the tests carried out with the carbon supports show some LA conversion and GVL yield (at $170{ }^{\circ} \mathrm{C}$, LA conversion is about $40 \%$ with $5 \%$ GVL yield, and at $70{ }^{\circ} \mathrm{C}$, about $11 \%$ LA is converted, without GVL formation). These results can be considered in agreement with those reported by Sudhakar et al. [30], who proved that, at $70{ }^{\circ} \mathrm{C}$ and 5 bar $\mathrm{H}_{2}, 2 \%$ LA conversion, with $99 \%$ selectivity to GVL, was achieved using hydroxyapatite support.

Table 4 shows the catalytic activity results obtained with the four tested catalysts in tests performed at $170{ }^{\circ} \mathrm{C}$.

Table 4. Catalytic activity results obtained with the $\mathrm{Ru}^{\mathrm{R}} / \mathrm{C}$ catalysts at $170^{\circ} \mathrm{C}$.

\begin{tabular}{ccccc}
\hline Catalyst & $\begin{array}{c}\text { LA Conversion } \\
\mathbf{( \% )}\end{array}$ & $\begin{array}{c}\text { GVL Yield } \\
\mathbf{( \% )}\end{array}$ & $\begin{array}{c}\text { GVL Selectivity } \\
\mathbf{( \% )}\end{array}$ & $\begin{array}{c}\mathbf{r}_{\mathbf{s}} \text { ** } \\
\left(\mathbf{h}^{-\mathbf{1}} \mathbf{)}\right.\end{array}$ \\
\hline $\mathrm{Ru}^{\mathrm{R}} / \mathrm{SA}-30$ & 100 & 82 & 82 & 340 \\
$\mathrm{Ru}^{\mathrm{R}} / \mathrm{WV}-1100$ & 100 & 87 & 87 & 340 \\
$\mathrm{Ru}^{\mathrm{R}} / \mathrm{ASC}$ & 96 & 81 & 84 & 327 \\
$\mathrm{Ru}^{\mathrm{R}} / \mathrm{LC}$ & 98 & 92 & 94 & 334 \\
\hline$* 045 \mathrm{~mL}$
\end{tabular}

${ }^{*} 0.445 \mathrm{~mL} \mathrm{LA}, 130 \mathrm{mg}$ catalyst, 15 bar $\mathrm{H}_{2}, 1 \mathrm{~h} .{ }^{* *}$ Specific reaction rate: mol of LA converted per mol Ru and per unit of time (h).

No other products apart from GVL have been detected in this study. Intermediates such as 4-hydroxypentanoic acid (HPA) or angelica lactone (AL) (Figure 2), are not present in the resulting solution. However, as the chromatographic column used for HPLC analysis, well suited for the analysis of LA and GVL, is not very appropriate for 1,4-pentanediol (PND) detection, the formation of this compound cannot be discarded. This would explain the fact that the selectivity to GVL did not reach $100 \%$.

Recycling tests have been performed with three of the catalysts, showing that they maintain their high LA conversion and GVL yield in a second catalytic run. Table 5 shows the obtained results. 
Table 5. Catalytic activity results obtained with the $\mathrm{Ru} / \mathrm{C}$ catalysts reused at $170{ }^{\circ} \mathrm{C} *$

\begin{tabular}{cccc}
\hline Catalyst & Conversion (\%) & GVL Yield (\%) & GVL Selectivity (\%) \\
\hline $\mathrm{Ru} / \mathrm{SA}-30$ run 1 & 100 & 82 & 82 \\
$\mathrm{Ru} / \mathrm{SA}-30$ run 2 & 100 & 78 & 78 \\
\hline $\mathrm{Ru} / \mathrm{ASC}$ run 1 & 96 & 81 & 84 \\
$\mathrm{Ru} / \mathrm{ASC}$ run 2 & 100 & 84 & 84 \\
\hline $\mathrm{Ru} / \mathrm{LC}$ run 1 & 98 & 92 & 94 \\
$\mathrm{Ru} / \mathrm{LC}$ run 2 & 100 & 94 & 94 \\
\hline
\end{tabular}

*0.445 mL LA, $130 \mathrm{mg}$ catalyst, 15 bar $\mathrm{H}_{2}, 1 \mathrm{~h}$.

The four catalysts show a very good catalytic behavior at $170{ }^{\circ} \mathrm{C}$, with LA conversion close to $100 \%$ and GVL yield above $80 \%$. Hence, operating at this reaction temperature, it is not possible to assess the relative influence of the properties of the catalysts (surface area, surface chemistry, and/or state of active species) in the catalytic behavior. Note that the mean nanoparticle size is similar in all the catalysts $(\sim 2 \mathrm{~nm})$, so it is not a decisive parameter to explain the differences in the catalytic behavior of the studied catalysts.

The obtained catalytic results are interesting, but to put them in context it is necessary to compare them with analogous results obtained with different $\mathrm{Ru} / \mathrm{C}$ catalysts reported in the literature. Such a comparison (Table 6) shows that the carbon supports used in the present work play a relevant role in the high performance of the prepared catalysts. Although reaction conditions differ in most of the reported studies, a general comparative analysis can be drawn from such a comparison.

Table 6. Comparison of reported results for LA hydrogenation with $\mathrm{Ru} / \mathrm{C}$ catalysts.

\begin{tabular}{|c|c|c|c|c|c|c|c|c|c|c|c|}
\hline Entry & Support & Ru wt.\% & $S / C^{a}$ & Solvent & $\begin{array}{c}\mathrm{T} \\
\left({ }^{\circ} \mathrm{C}\right)\end{array}$ & $\begin{array}{c}P \\
\text { (bar) }\end{array}$ & $\begin{array}{c}t \\
(\min )\end{array}$ & $\begin{array}{c}\text { Conv. } \\
\text { (\%) }\end{array}$ & $\begin{array}{l}\text { Sel. } \\
(\%)\end{array}$ & $\begin{array}{c}\mathbf{r}_{\mathrm{s}}{ }^{*} \\
\left(\mathbf{h}^{-1}\right)\end{array}$ & Ref. \\
\hline 1 & $\mathrm{C}$ (not specified) & 5 & 348 & methanol & 130 & 12 & 160 & 92 & 91 & 129 & [25] \\
\hline 2 & $C$ (not specified) & 5 & - & dioxane & 150 & 55 & 120 & 80 & 72 & - & [19] \\
\hline 3 & $C$ (not specified) & 5 & - & dioxane & 150 & 34 & 240 & 100 & 97 & - & [19] \\
\hline 4 & C-DARCO ${ }^{b}$ & 5 & 58 & water & 190 & 10 & 60 & 87 & 75 & 49 & [31] \\
\hline 5 & $\mathrm{C}^{\mathrm{c}-\mathrm{h}}$ & 5 & 58 & water & 190 & 10 & 60 & $80-95$ & $80-87$ & $44-55$ & [24] \\
\hline 6 & $A C^{i}$ & 4 & 2256 & water & 100 & 50 & 180 & 43 & 91 & 329 & [32] \\
\hline 7 & $\mathrm{rGO}^{\mathrm{j}}$ & 4 & 2256 & water & 100 & 50 & 180 & 100 & 80 & 764 & [32] \\
\hline 8 & C (Table 2) & 1 & 338 & water & 170 & 15 & 60 & $96-100$ & $82-94$ & $327-340$ & This work \\
\hline
\end{tabular}

* Specific reaction rate: mol of LA converted per mol Ru per unit of time (h). ${ }^{\text {a: }}$ Substrate/catalyst ratio, initial LA moles/Ru moles in the catalyst; ${ }^{b}$ : from Sigma Aldrich; ${ }^{\text {c: }}$ (grain size $<0.1 \mathrm{~mm}$ ) from ChemPur, Piekary Ślaskie, Poland; ${ }^{\text {: }}$ (grain size $<0.1 \mathrm{~mm}$ ) from ChemPur, Piekary Ślaskie, Poland; ${ }^{\text {e: }}$ (grain size $<0.1 \mathrm{~mm}$ ) from Gryfskand, Gryfino, Poland; ${ }^{\text {f-h }}$ : grain size $<0.1 ; 0.25-0.5 ; 0.75-1 \mathrm{~mm}$, respectively. From by Windsor Laboratories, Ltd., Slough-Berkshire, $\mathrm{UK}^{;}{ }^{\mathrm{i}}$ : AC produced from olive stones; ${ }^{\mathrm{j}}$ : reduced graphene oxide.

As shown in Table 6, most of the reported studies deal with 4-5 wt.\% Ru catalysts, while the present work leads to comparable conversion and selectivity results with a much lower Ru loading, 1 wt.\%.

As reported by Yan et al. [25] (entry 1) a high LA conversion and GVL yield has been obtained with a $5 \mathrm{wt} . \% \mathrm{Ru} / \mathrm{C}$ catalyst using methanol as a solvent at $130{ }^{\circ} \mathrm{C}$ under $12 \mathrm{bar}$ $\mathrm{H}_{2}$ in 160 min reaction time. Although the authors do not give details about the catalyst support, they seem to have used a commercial one. In any case, information on the carbon properties is not provided.

Manzer [19] (entries 2 and 3) has studied the LA hydrogenation to GVL as the first step in the production of $\alpha$-methylene- $\gamma$-valerolactone (MeMLB) at $150{ }^{\circ} \mathrm{C}$ in dioxane. The authors prepared the catalyst by incipient wetness impregnation with a metal salt solution, followed by reduction with $\mathrm{H}_{2}\left(400{ }^{\circ} \mathrm{C}, 2 \mathrm{~h}\right)$, but neither details about the properties of the carbon used as support, nor the catalyst dosage are detailed. 100\% LA conversion and $97 \%$ selectivity to GVL were obtained in 240 min using 34 bar $\mathrm{H}_{2}$ (entry 3). 
In the work of Ruppert et al. [31] (entry 4), the catalyst was prepared with the commercial activated carbon C-DARCO, but the authors did not give information about surface area or surface chemistry (it is probably a support with around $1600 \mathrm{~m}^{2} / \mathrm{g}$ ). LA hydrogenation was

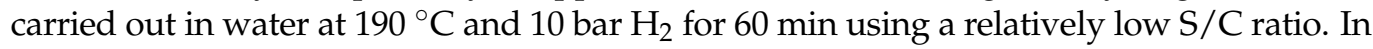
these conditions, although LA conversion was high, the specific reaction rate was low.

A recent work of Jedrzejczyk et al. [24] has focused on the nature of the carbon material used as support for Ru/C catalysts (entry 5). These authors have used four commercial carbon materials with surface area ranging from 649 to $973 \mathrm{~m}^{2} / \mathrm{g}$ and some derived samples with different grain size. Reaction conditions are $190^{\circ} \mathrm{C}, 10 \mathrm{bar} \mathrm{H}_{2}, 60 \mathrm{~min}$, and $\mathrm{S} / \mathrm{C}$ ratio of 58. The study has included a good characterization of supports and catalysts, and some differences in acidic properties are reported for them. However, the authors attribute the observed differences in catalytic activity to a different metal-support interaction strength related to defects on the surface of the carbon material and the type of Ru species. In their study, the most active catalyst is the one with the highest number of defects, which, according to the authors, stimulate the strong interaction of the metal with the support.

Finally, the work of Song et al. [32] deals also with $\mathrm{Ru} / \mathrm{C}$ catalysts prepared with quite different carbon materials (an AC from olive stones, high surface graphite, carbon nanotubes, and reduced graphene oxide). Entries 6 and 7 show the data corresponding to the highest and lowest LA conversion achieved. With all the studied catalysts, excepting $\mathrm{Ru} / \mathrm{AC}$, selectivity to GVL is $80 \%$. The differences in the catalysts' behavior are attributed to differences in the $\mathrm{Ru}$ particle size $(2.9 \mathrm{~nm}$ in $\mathrm{Ru} / \mathrm{AC}$ and $1.2 \mathrm{~nm}$ in $\mathrm{Ru} / \mathrm{rGO})$. The reported catalytic behavior is very good.

This comparison with literature results indicates that the catalysts reported in the present work show, with much lower Ru content, a comparable or in some cases even better catalytic behavior, with a high specific reaction rate and a very high selectivity to GVL (entry 8). This good behavior is probably due to the properties of the carbon materials used as support, but also to the selected reaction conditions.

To better analyze the effect of the carbon properties of these supported ruthenium catalysts, and also to perform LA hydrogenation in milder and less energy-demanding reaction conditions, a second set of catalytic activity tests has been carried out at $70{ }^{\circ} \mathrm{C}$.

The obtained results (Figure 7) show that, at this lower temperature, the four catalysts present a significantly different behavior, which would be related to the carbon support properties. Thus, at high reaction temperature, the four catalysts give a high LA conversion, close to $100 \%$, but as the reaction temperature decreases, the particular features of the catalysts show their influence in the process.

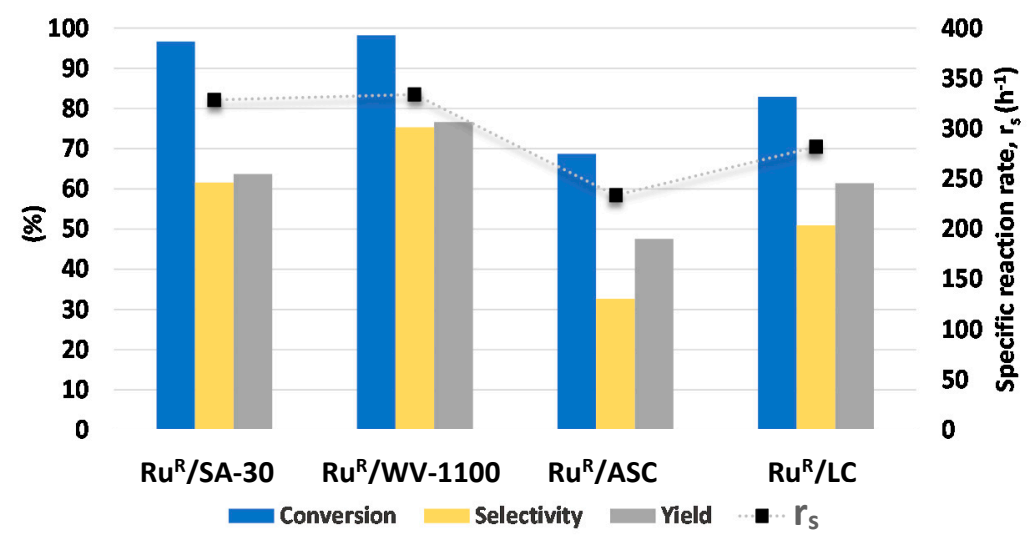

Figure 7. LA conversion, GVL yield, and selectivity to GVL obtained with the $\mathrm{Ru}^{\mathrm{R}} / \mathrm{C}$ catalyst at $70{ }^{\circ} \mathrm{C}\left(0.445 \mathrm{~mL} \mathrm{LA}, 130 \mathrm{mg}\right.$ catalyst, 15 bar H$\left._{2}, 1 \mathrm{~h}\right)$.

Compared to the results obtained at $170{ }^{\circ} \mathrm{C}$, LA conversion at $70{ }^{\circ} \mathrm{C}$ is only slightly lower in the case of $\mathrm{Ru}^{\mathrm{R}} / \mathrm{SA}-30$ and $\mathrm{Ru}^{\mathrm{R}} / \mathrm{WV}-1100$ catalysts, but it is about $15 \%$ and $30 \%$ lower for $\mathrm{Ru}^{\mathrm{R}} / \mathrm{LC}$ and for $\mathrm{Ru}^{\mathrm{R}} / \mathrm{ASC}$ catalysts, respectively (these changes are also observed 
in the $\mathrm{r}_{\mathrm{S}}$ values). As the LA conversion at $70{ }^{\circ} \mathrm{C}$ for two catalysts is only slightly lower than at $170{ }^{\circ} \mathrm{C}$, it can be assumed that the effect of temperature on the hydrogen diffusion in the solvent is not very important [25]. The poorer LA conversion and selectivity to GVL shown by the biomass-derived carbon-supported catalysts suggests that the support acidity plays a relevant role in the process, in agreement with $[14,30,47,48]$. It can be assumed that if the support acidity is lower, as in the case of $\mathrm{Ru}^{\mathrm{R}} / \mathrm{ASC}$ and $\mathrm{Ru}^{\mathrm{R}} / \mathrm{LC}$, the dehydration step required to convert LA into GVL is hindered (see reaction scheme in Figure 2).

Then, these results highlight the important influence of the surface chemistry of the carbon supports on the catalytic performance of the $\mathrm{Ru} / \mathrm{C}$ catalysts under mild conditions, being the acidity of the catalysts that favors the LA hydrogenation and selectivity to GVL. It can be then concluded that the reaction temperature can be lowered, maintaining a high activity if a carbon support with a suitable acidity is chosen.

It must also be pointed out that at $70{ }^{\circ} \mathrm{C}$ the $\mathrm{Ru}^{\mathrm{R}} / \mathrm{WV}-1100$ catalyst keeps a GVL yield relatively close to the one obtained at $170{ }^{\circ} \mathrm{C}(75 \%$ vs. $87 \%)$, showing good catalytic performance at this relatively low reaction temperature.

Reported studies using such a low temperature for LA conversion to GVL are scarce. For example, Yao et al. [29] performed the reaction at $70{ }^{\circ} \mathrm{C}$, but at $30 \mathrm{bar}_{2}$ for $120 \mathrm{~min}$ with a commercial $2 \mathrm{wt}$ \% $\mathrm{Ru} / \mathrm{C}$ catalysts $\left(1850 \mathrm{~m}^{2} / \mathrm{g}\right)$. Using an S/C ratio of 348 , they obtained an $\mathrm{r}_{\mathrm{S}}$ value of $95 \mathrm{~h}^{-1}$ (much lower than the one obtained for most of the catalysts in this work (Figure 7)). In the work of Galletti et al. [49], the reaction was also carried out at $70{ }^{\circ} \mathrm{C}$ and 30 bar $\mathrm{H}_{2}$, but acid agents were also used to increase the activity. They found that the combination of Amberlyst A70, or niobium phosphate, with a commercial $5 \mathrm{wt} . \%$ $\mathrm{Ru} / \mathrm{C}$ catalyst $\left(880 \mathrm{~m}^{2} / \mathrm{g}\right)$ led to a catalytic system that produced a high GVL yield (99\%) in $3 \mathrm{~h}$ reaction time and $\mathrm{r}_{\mathrm{s}}$ value of $558 \mathrm{~h}^{-1}$.

The use of a reaction temperature as low as $70{ }^{\circ} \mathrm{C}$ is a promising alternative to increase the energetic efficiency of the process. The optimization of the operation conditions, together with the modification of the catalyst acidity to obtain more efficient bifunctional catalysts, could improve the good catalytic results already achieved in the present study for this reaction.

\section{Materials and Methods}

\subsection{Materials}

The carbon materials used as supports to prepare the $\mathrm{Ru} / \mathrm{C}$ catalysts are two commercial activated carbons from MeadWestvaco (now Ingevity Corporation, North Charleston, SC, USA), named SA-30 and WV-1100, and two activated carbons prepared from biomass residues by activation with phosphoric acid $\left(\mathrm{H}_{3} \mathrm{PO}_{4}\right)$. ASC was prepared by hydrothermal carbonization from almond shells in conditions, such as those reported in [50]. Milled almond shells were mixed with an aqueous $\mathrm{H}_{3} \mathrm{PO}_{4}$ solution (25 wt.\%) in a stainless-steel autoclave $\left(\mathrm{H}_{3} \mathrm{PO}_{4} /\right.$ almond shell wt. ratio $\left.=1\right)$ and heated at $200{ }^{\circ} \mathrm{C}$ for $24 \mathrm{~h}$. The resulting hydrochar was then heated $\left(450^{\circ} \mathrm{C}, 2 \mathrm{~h}, \mathrm{~N}_{2} 50 \mathrm{~mL} \mathrm{~min}^{-1}\right)$. Afterward, the sample was washed with distilled water at $65^{\circ} \mathrm{C}$ and dried at $110{ }^{\circ} \mathrm{C}$ overnight. LC was prepared from Luffa Cylindrica, a lignocellulosic plant original from the region of Metidja in northern Algeria (commonly called loofah sponge, by chemical activation using $85 \%$ phosphoric acid, in a $\mathrm{H}_{3} \mathrm{PO}_{4} / \mathrm{LAC}$ wt. ratio of $5 / 1$, at $550{ }^{\circ} \mathrm{C}, 1 \mathrm{~h}, \mathrm{~N}_{2} 60 \mathrm{~mL} \mathrm{~min}{ }^{-1}$. The obtained carbon was washed many times with distilled water, using a Soxhlet, until a neutral $\mathrm{pH}$ and dried $\left(105^{\circ} \mathrm{C}, 24 \mathrm{~h}\right)$.

$\mathrm{RuCl}_{3}$ (45-55 wt.\% Ru), levulinic acid (98\%), and gamma-valerolactone (99\%) were purchased from Sigma Aldrich (St. Louis, MO, USA).

\subsection{Catalysts Preparation}

Carbon supported Ru catalysts were prepared by impregnation using an aqueous solution of $\mathrm{RuCl}_{3}(18 \mathrm{~mL}$ solution/g of support) of the appropriate concentration $(0.56 \mathrm{mmol} / \mathrm{L})$ to get $1 \mathrm{wt} . \% \mathrm{Ru}$ (nominal content). The mixture was mechanically stirred for $24 \mathrm{~h}$ and then ultrasonicated for $3 \mathrm{~h}$. Finally, the solvent was removed in a stove at $115^{\circ} \mathrm{C}$. 
The as-prepared catalysts are named Ru/Sup, where Sup is the name of the carbon material used as support as indicated before. If they have been submitted to a reduction treatment $\left(250^{\circ} \mathrm{C}, \mathrm{H}_{2}(75 \mathrm{~mL} / \mathrm{min}), 4 \mathrm{~h}\right)$ the name includes the letter " $\mathrm{R}$ " as a superscript $\left(\mathrm{Ru}^{\mathrm{R}} / \mathrm{Sup}\right)$.

\subsection{Characterization of Supports and Catalysts}

The surface area and porosity of supports and catalysts were characterized by gas adsorption, $\mathrm{N}_{2}$ at $-196{ }^{\circ} \mathrm{C}$ and $\mathrm{CO}_{2}$ at $0{ }^{\circ} \mathrm{C}$ [51,52], using a volumetric Autosorb-6B apparatus from Quantachrome. Before the analysis, the samples were degassed at $250{ }^{\circ} \mathrm{C}$ for $4 \mathrm{~h}$. The apparent surface area $\left(\mathrm{S}_{\mathrm{BET}}\right)$ was calculated by application of the BET equation to the nitrogen adsorption data [53]. The Dubinin-Radushkevich equation was applied to the $\mathrm{N}_{2}$ and $\mathrm{CO}_{2}$ adsorption isotherms to determine the total micropore volume $\left(\mathrm{V}_{\mathrm{DR}}, \mathrm{N} 2\right.$, micropores smaller than $2 \mathrm{~nm})$ and the narrow micropore volume $\left(\mathrm{V}_{\mathrm{DR}}, \mathrm{CO} 2\right.$, micropores smaller than $0.7 \mathrm{~nm}$ ), respectively [54]. The difference between $\mathrm{V}_{\mathrm{DR}, \mathrm{N} 2}$ and $\mathrm{V} \mathrm{DR}_{\mathrm{C}} \mathrm{CO} 2$ is known as $\mathrm{V}_{\text {super micro }}[51,53]$. The mesopore volume $\left(\mathrm{V}_{\text {meso, }}\right.$ pores of size between 2 and $20 \mathrm{~nm}$ ) was estimated as the difference of the volume of $\mathrm{N}_{2}$ adsorbed as a liquid at $\mathrm{P} / \mathrm{P}_{0}=0.9$ and at $\mathrm{P} / \mathrm{P}_{0}=0.2$ [53], while the total pore volume $\left(\mathrm{V}_{\mathrm{T}}\right)$ corresponds to the volume of $\mathrm{N}_{2}$ adsorbed as a liquid at $\mathrm{P} / \mathrm{P}_{0}=0.99$.

The surface chemistry of the supports was studied by temperature-programmed desorption (TPD) in the following conditions: about $10 \mathrm{mg}$ of the sample were heated at $20^{\circ} \mathrm{C} / \mathrm{min}$ in He flow $(100 \mathrm{~mL} / \mathrm{min})$ up to $950{ }^{\circ} \mathrm{C}$. The equipment used consists of a thermobalance (TA-SDT Q600) coupled to a mass spectrometer (Thermostar, Balzers, Pfeiffer Vacuum, Asslar, Germany) allowing the simultaneous record of weight loss and analysis of evolved gases $\left(\mathrm{CO}_{2}, \mathrm{CO}\right.$, and $\left.\mathrm{H}_{2} \mathrm{O}\right)$.

X-ray photoelectron spectroscopy (XPS, VGMicrotech Multilab ESCA-3000 spectrometer, ThermoFisher Scientific, Waltham, MA, USA) was used to characterize the surface chemical composition of the catalysts and the electronic states of the supported Ru species. $\mathrm{Ru} 3 \mathrm{p}$ electrons were analyzed (instead of $3 \mathrm{~d}$ ones) since $\mathrm{Ru} 3 \mathrm{~d}$ and $\mathrm{C} 1 \mathrm{~s}$ electrons have similar B.E. [42,55].

Transmission electron microscopy (TEM, JEM-2010 with digital camera GATAN ORIUS SC600, (JEOL, Tokyo, Japan)) was used to analyze the size and distribution of the $\mathrm{Ru}$ particles in the reduced catalysts. Particle size was measured with the ImageJ program.

\subsection{Catalytic Activity Tests}

In a typical LA hydrogenation catalytic test $0.445 \mathrm{~mL} \mathrm{LA}, 130 \mathrm{mg}$ catalyst, and $25 \mathrm{~mL}$ distilled water were mixed in the Teflon insert of a $100 \mathrm{~mL}$ stainless-steel batch reactor (Parr Instrument Company, Moline, IL, USA). After purging with He and under mechanical stirring (500 rpm), the $\mathrm{H}_{2}$ pressure was increased up to 15 bar at the selected reaction temperature $\left(170{ }^{\circ} \mathrm{C}\right.$ or $\left.70{ }^{\circ} \mathrm{C}\right)$ and then, the system was kept in these conditions for $1 \mathrm{~h}$. Afterward, the reactor was cooled down to room temperature and depressurized, and then the solid and liquid phases were separated by sedimentation. The supernatant solution was collected and filtrated with a syringe (filter of $0.45 \mu \mathrm{m}$ ) to be analyzed by High-Performance Liquid Chromatography (HPLC, Agilent 1100 series, Santa Clara, CA, USA), equipped with UV-Visible Variable Wavelength Detector) coupled to a Mass Trap Spectrometer (MS) with Ion Trap Analyzer (Agilent 1100 Series LC/MSD Trap SL, Santa Clara, CA, USA). The column used was ZORBAX Eclipse XDB-C8 (Agilent, Santa Clara, CA, USA) (dimensions $\left.4.6 \times 150 \mathrm{~m}^{2}\right)$. More details can be found in Table S3.

Blank experiments, without catalyst and with the carbon supports, were carried out in the same conditions and following the same procedures.

After catalytic tests at $170{ }^{\circ} \mathrm{C}$, the liquid and solid phases were separated by sedimentation, and then the solution was removed and filtered using a syringe. In each case, the catalyst was washed with three portions $(25 \mathrm{~mL})$ of distilled water and dried $\left(115^{\circ} \mathrm{C}, 24 \mathrm{~h}\right)$. 
Then, a second catalytic run was performed with the recovered catalyst under the same reaction conditions.

\subsection{Product Analysis}

LA conversion, GVL yield, selectivity to GVL and specific reaction rate were calculated as follows:

$$
\begin{gathered}
\text { LA conversion }(\%)=\frac{\mathrm{n}_{\mathrm{LA}, \text { initial }}-\mathrm{n}_{\mathrm{LA}, \text { final }}}{\mathrm{n}_{\mathrm{LA}, \text { initial }}} \times 100 \\
\text { GVL yield }(\%)=\frac{\mathrm{n}_{\mathrm{GVL}}}{\mathrm{n}_{\mathrm{LA} \text {,initial }}} \times 100 \\
\text { GVL selectivity }(\%)=\frac{\text { Yield }}{\text { Conversion }} \times 100 \\
\text { Specific reaction rate, } \mathrm{r}_{\mathrm{s}}\left(\mathrm{h}^{-1}\right)=\frac{\mathrm{n}_{\mathrm{LA}, \text { initial }}-\mathrm{n}_{\mathrm{LA}, \text { final }}}{\mathrm{n}_{\mathrm{Ru}} \times \mathrm{t}} \times 100
\end{gathered}
$$

where $\mathrm{n}_{\mathrm{LA} \text {,initial }}$ represents the number of moles of LA added to the reactor and $\mathrm{n}_{\mathrm{LA}}$, final and $n_{G V L}$ represent the number of moles of LA and GVL in the liquid reaction product, respectively. $n_{R u}$ represents the number of moles of the active phase in the catalyst and $t$ is the reaction time. Calibration was carried out using several standard and independent solutions of LA and GVL.

\section{Conclusions}

Active and selective $\mathrm{Ru} / \mathrm{C}$ catalysts for the hydrogenation of levulinic acid to gammavalerolactone have been prepared using as supports two commercial and two biomassderived activated carbons (ACs).

The four $\mathrm{Ru} / \mathrm{C}$ tested catalysts present a very high LA conversion and GVL yield when the reaction is performed at $170{ }^{\circ} \mathrm{C}$. Thus, in these conditions the different support properties do not lead to differences between the catalysts, although they seem to be appropriate to achieve efficient catalysts. The prepared catalysts have shown a catalytic behavior superior to that of many of the $\mathrm{Ru} / \mathrm{C}$ catalysts reported in the literature.

At lower reaction temperature $\left(70{ }^{\circ} \mathrm{C}\right)$, noticeable differences between the catalysts' behavior have been observed. The two catalysts prepared with the commercial ACs show better performance, which has been attributed to the higher acidic character of these materials. In particular, the catalyst prepared with the WV-1100 AC shows $98 \%$ LA conversion and $77 \%$ selectivity to GVL, with a specific reaction rate $\left(r_{\mathrm{s}}\right)$ value very close to that obtained at $170{ }^{\circ} \mathrm{C}$. These results highlight the importance of the support's surface chemistry and allow us to conclude that the reaction temperature can be lowered, maintaining a high activity if a carbon support with a suitable acidity is chosen. This also leads to the next research step, focused on the functionalization of the biomass-derived ACs to increase their acidity.

Supplementary Materials: The following are available online at https: / www.mdpi.com/article/10 .3390 / catal11050559/s1, Table S1. Amount of $\mathrm{CO}_{2}$ and CO from TPD experiments and calculated total oxygen content in the $\mathrm{Ru} / \mathrm{C}$ catalysts (as prepared and reduced); Table S2. Mean nanoparticle size and the error associated; Table S3. Details of the HPLC analysis; Figure S1. TPD spectra of carbon supports and reduced catalysts: $\mathrm{CO}_{2}$ and $\mathrm{CO}$ evolution (be aware of the different scale in yaxis); Figure S2. Pore volume data comparison for supports and reduced catalysts. Figure S3. Particle size distribution for: (a) $\mathrm{Ru}^{\mathrm{R}} / \mathrm{SA}-30$ (inset: particle size distribution beyond $4 \mathrm{~nm}$ ), (b) $\mathrm{Ru} / \mathrm{RV}-1100$, (c) $\mathrm{Ru}^{\mathrm{R}} /$ ASC and (d) $\mathrm{Ru}^{\mathrm{R}} / \mathrm{LC}$.

Author Contributions: Conceptualization, M.Á.L.-R. and M.d.C.R.-M.; methodology, Z.R.-B., M.Á.L.R. and M.d.C.R.-M.; investigation, Z.R.-B., M.Á.L.-R. and M.d.C.R.-M.; resources, M.Á.L.-R. and M.d.C.R.-M.; data curation, Z.R.-B., M.Á.L.-R. and M.d.C.R.-M.; writing-original draft preparation, Z.R.-B., M.Á.L.-R. and M.d.C.R.-M.; writing—review and editing, Z.R.-B., M.Á.L.-R. and M.d.C.R.-M.; supervision, M.Á.L.-R. and M.d.C.R.-M.; project administration, M.Á.L.-R. and M.d.C.R.-M.; funding 
acquisition, M.Á.L.-R. and M.d.C.R.-M. All authors have read and agreed to the published version of the manuscript.

Funding: This research was funded by the Spanish Ministry of Science, Innovation and Universities (RTI2018-095291-B-I00), Generalitat Valenciana (PROMETEO/2018/076), European ComissionFEDER, and the University of Alicante (VIGROB-136).

Data Availability Statement: The data presented in this study are available in this article and in the Supplementary Materials.

Acknowledgments: Z.R.-B. thanks the Spanish Ministry of Science, Innovation and Universities for the predoctoral scholarship, reference PRE2019-090049. Z.R.-B., M.Á.L-R. and M.d.C.R.-M. thank J. Chaparro-Garnica and S. Boumad for providing ASC and LC carbon materials, respectively.

Conflicts of Interest: The authors declare no conflict of interest.

\section{References}

1. Alonso, D.M.; Bond, J.Q.; Dumesic, J.A. Catalytic conversion of biomass to biofuels. Green Chem. 2010, 12, 1493-1513. [CrossRef]

2. Serrano-Ruiz, J.C.; Luque, R.; Sepúlveda-Escribano, A. Transformations of biomass-derived platform molecules: From high added-value chemicals to fuels via aqueous-phase processing. Chem. Soc. Rev. 2011, 40, 5266-5281. [CrossRef]

3. Anjali, K.; Venkatesha, N.J.; Christopher, J.; Sakthivel, A. Rhodium porphyrin molecule-based catalysts for the hydrogenation of biomass derived levulinic acid to biofuel additive $\gamma$-valerolactone. New J. Chem. 2020, 44, 11064-11075. [CrossRef]

4. Weingarten, R.; Conner, W.C.; Huber, G.W. Production of levulinic acid from cellulose by hydrothermal decomposition combined with aqueous phase dehydration with a solid acid catalyst. Energy Environ. Sci. 2012, 5, 7559. [CrossRef]

5. Alonso, D.M.; Wettstein, S.G.; Dumesic, J.A. Gamma-valerolactone, a sustainable platform molecule derived from lignocellulosic biomass. Green Chem. 2013, 15, 584-595. [CrossRef]

6. Du, X.L.; Bi, Q.Y.; Liu, Y.M.; Cao, Y.; Fan, K.N. Conversion of biomass-derived levulinate and formate esters into $\gamma$-valerolactone over supported gold catalysts. ChemSusChem 2011, 4, 1838-1843. [CrossRef] [PubMed]

7. Galletti, A.M.R.; Antonetti, C.; De Luise, V.; Licursi, D.; Di Nasso, N.N.O. Levulinic acid production from waste biomass. BioResources 2012, 7, 1824-1835. [CrossRef]

8. Wang, Y.; Vernières-Hassimi, L.; Casson-Moreno, V.; Hébert, J.P.; Leveneur, S. Thermal risk assessment of levulinic acid hydrogenation to $\gamma$-valerolactone. Org. Process Res. Dev. 2018, 22, 1092-1100. [CrossRef]

9. Horváth, I.T.; Mehdi, H.; Fábos, V.; Boda, L.; Mika, L.T. $\gamma$-Valerolactone-a sustainable liquid for energy and carbon-based chemicals. Green Chem. 2008, 10, 238-242. [CrossRef]

10. Mafokoane, M.; Seguel, J.; García, R.; Díaz de León, J.N.; Sepúlveda, C.; Escalona, N. Conversion of levulinic acid using $\mathrm{CuO} / \mathrm{WO}_{3}(\mathrm{x})-\mathrm{Al}_{2} \mathrm{O}_{3}$ catalysts. Catal. Today 2020, 367, 310-319. [CrossRef]

11. Dutta, S.; Yu, I.K.M.; Tsang, D.C.W.; Ng, Y.H.; Ok, Y.S.; Sherwood, J.; Clark, J.H. Green synthesis of gamma-valerolactone (GVL) through hydrogenation of biomass-derived levulinic acid using non-noble metal catalysts: A critical review. Chem. Eng. J. 2019, 372, 992-1006. [CrossRef]

12. Tang, X.; Zeng, X.; Li, Z.; Hu, L.; Sun, Y.; Liu, S.; Lei, T.; Lin, L. Production of $\gamma$-valerolactone from lignocellulosic biomass for sustainable fuels and chemicals supply. Renew. Sustain. Energy Rev. 2014, 40, 608-620. [CrossRef]

13. Hengst, K.; Schubert, M.; Carvalho, H.W.P.; Lu, C.; Kleist, W.; Grunwaldt, J.D. Synthesis of $\gamma$-valerolactone by hydrogenation of levulinic acid over supported nickel catalysts. Appl. Catal. A Gen. 2015, 502, 18-26. [CrossRef]

14. Luo, W.; Deka, U.; Beale, A.M.; Van Eck, E.R.H.; Bruijnincx, P.C.A.; Weckhuysen, B.M. Ruthenium-catalyzed hydrogenation of levulinic acid: Influence of the support and solvent on catalyst selectivity and stability. J. Catal. 2013, 301, 175-186. [CrossRef]

15. Abdelrahman, O.A.; Heyden, A.; Bond, J.Q. Analysis of kinetics and reaction pathways in the aqueous-phase hydrogenation of levulinic acid to form $\gamma$-Valerolactone over Ru/C. ACS Catal. 2014, 4, 1171-1181. [CrossRef]

16. Wright, W.R.H.; Palkovits, R. Development of heterogeneous catalysts for the conversion of levulinic acid to $\gamma$-valerolactone. ChemSusChem 2012, 5, 1657-1667. [CrossRef] [PubMed]

17. Starodubtseva, E.V.; Turova, O.V.; Vinogradov, M.G.; Gorshkova, L.S.; Ferapontov, V.A. Enantioselective hydrogenation of levulinic acid esters in the presence of the Ru ${ }^{\mathrm{II}}$-BINAP-HCl catalytic system. Russ. Chem. Bull. 2005, 54, 2374-2378. [CrossRef]

18. Mehdi, H.; Fábos, V.; Tuba, R.; Bodor, A.; Mika, L.T.; Horváth, I.T. Integration of homogeneous and heterogeneous catalytic processes for a multi-step conversion of biomass: From sucrose to levulinic acid, $\gamma$-valerolactone, 1,4-pentanediol, 2-methyltetrahydrofuran, and alkanes. Top. Catal. 2008, 48, 49-54. [CrossRef]

19. Manzer, L.E. Catalytic synthesis of $\alpha$-methylene- $\gamma$-valerolactone: A biomass-derived acrylic monomer. Appl. Catal. A Gen. 2004, 272, 249-256. [CrossRef]

20. Selva, M.; Gottardo, M.; Perosa, A. Upgrade of biomass-derived levulinic acid via Ru/C-catalyzed hydrogenation to $\gamma$ valerolactone in aqueous-organic-ionic liquids multiphase systems. ACS Sustain. Chem. Eng. 2013, 1, 180-189. [CrossRef]

21. Feng, J.; Gu, X.; Xue, Y.; Han, Y.; Lu, X. Production of $\gamma$-valerolactone from levulinic acid over a Ru/C catalyst using formic acid as the sole hydrogen source. Sci. Total Environ. 2018, 633, 426-432. [CrossRef] 
22. Glotov, A.; Novikov, A.; Stavitskaya, A.; Nedolivko, V.; Kopitsyn, D.; Kuchierskaya, A.; Ivanov, E.; Stytsenko, V.; Vinokurov, V.; Lvov, Y. Nanoreactors based on hydrophobized tubular aluminosilicates decorated with ruthenium: Highly active and stable catalysts for aromatics hydrogenation. Catal. Today 2020. [CrossRef]

23. Glotov, A.; Vutolkina, A.; Pimerzin, A.; Nedolivko, V.; Zasypalov, G.; Stytsenko, V.; Karakhanov, E.; Vinokurov, V. Ruthenium catalysts templated on mesoporous MCM-41 type silica and natural clay nanotubes for hydrogenation of benzene to cyclohexane. Catalysts 2020, 10, 537. [CrossRef]

24. Jęrzejczyk, M.; Soszka, E.; Goscianska, J.; Kozanecki, M.; Grams, J.; Ruppert, A.M. The influence of carbon nature on the catalytic performance of $\mathrm{Ru} / \mathrm{C}$ in levulinic acid hydrogenation with Internal Hydrogen Source. Molecules 2020, 25, 5362. [CrossRef]

25. Yan, Z.P.; Lin, L.; Liu, S. Synthesis of $\gamma$-valerolactone by hydrogenation of biomass- derived levulinic acid over Ru/C catalyst. Energy Fuels 2009, 23, 3853-3858. [CrossRef]

26. Bourne, R.A.; Stevens, J.G.; Ke, J.; Poliakoff, M. Maximising opportunities in supercritical chemistry: The continuous conversion of levulinic acid to $\gamma$-valerolactone in $\mathrm{CO}_{2}$. Chem. Commun. 2007, 44, 4632-4634. [CrossRef] [PubMed]

27. Hengne, A.M.; Rode, C.V. Cu- $\mathrm{rrO}_{2}$ nanocomposite catalyst for selective hydrogenation of levulinic acid and its ester to $\gamma$-valerolactone. Green Chem. 2012, 14, 1064-1072. [CrossRef]

28. Primo, A.; Concepción, P.; Corma, A. Synergy between the metal nanoparticles and the support for the hydrogenation of functionalized carboxylic acids to diols on $\mathrm{Ru} / \mathrm{TiO}_{2}$. Chem. Commun. 2011, 47, 3613-3615. [CrossRef] [PubMed]

29. Yao, Y.; Wang, Z.; Zhao, S.; Wang, D.; Wu, Z.; Zhang, M. A stable and effective Ru/polyethersulfone catalyst for levulinic acid hydrogenation to $\gamma$-valerolactone in aqueous solution. Catal. Today 2014, 234, 245-250. [CrossRef]

30. Sudhakar, M.; Lakshmi Kantam, M.; Swarna Jaya, V.; Kishore, R.; Ramanujachary, K.V.; Venugopal, A. Hydroxyapatite as a novel support for Ru in the hydrogenation of levulinic acid to $\gamma$-valerolactone. Catal. Commun. 2014, 50, 101-104. [CrossRef]

31. Ruppert, A.M.; Jędrzejczyk, M.; Sneka-Płatek, O.; Keller, N.; Dumon, A.S.; Michel, C.; Sautet, P.; Grams, J. Ru catalysts for levulinic acid hydrogenation with formic acid as a hydrogen source. Green Chem. 2016, 18, 2014-2028. [CrossRef]

32. Song, W.; Lozano-Martin, M.C.; Gallegos-Suarez, E.; Ramirez-Barria, C.; Weng, W.; Yi, X.; Bachiller-Baeza, B.; Guerrero-Ruiz, A.; Rodriguez-Ramos, I. New insights in the development of carbon supported ruthenium catalysts for hydrogenation of levulinic acid. Curr. Catal. 2018, 7, 129-137. [CrossRef]

33. Thommes, M.; Kaneko, K.; Neimark, A.V.; Olivier, J.P.; Rodríguez-Reinoso, F.; Rouquerol, J.; Sing, K.S.W. Physisorption of gases, with special reference to the evaluation of surface area and pore size distribution (IUPAC Technical Report). Pure Appl. Chem. 2015, 87, 1051-1069. [CrossRef]

34. Figueiredo, J.L.; Pereira, M.F.R. The role of surface chemistry in catalysis with carbons. Catal. Today 2010, 150, 2-7. [CrossRef]

35. Figueiredo, J.L.; Pereira, M.F.R.; Freitas, M.M.A.; Órfão, J.J.M. Modification of the surface chemistry of activated carbons. Carbon 1999, 37, 1379-1389. [CrossRef]

36. Szymański, G.S.; Karpiński, Z.; Biniak, S.; Światkowski, A. The effect of the gradual thermal decomposition of surface oxygen species on the chemical and catalytic properties of oxidized activated carbon. Carbon 2002, 40, 2627-2639. [CrossRef]

37. Román-Martínez, M.C.; Cazorla-Amorós, D.; Linares-Solano, A.; Salinas-Martínez de Lecea, C. TPD and TPR characterization of carbonaceous supports and Pt/C catalysts. Carbon 1993, 31, 895-902. [CrossRef]

38. Azar, F.-Z.; Lillo-Ródenas, M.A.; Román-Martínez, M.C. Cellulose hydrolysis catalysed by mesoporous activated carbons functionalized under mild conditions. SN Appl. Sci. 2019, 1, 1739. [CrossRef]

39. Valero-Romero, M.J.; García-Mateos, F.J.; Rodríguez-Mirasol, J.; Cordero, T. Role of surface phosphorus complexes on the oxidation of porous carbons. Fuel Process. Technol. 2017, 157, 116-126. [CrossRef]

40. Peng, G.; Gramm, F.; Ludwig, C.; Vogel, F. Effect of carbon surface functional groups on the synthesis of Ru/C catalysts for supercritical water gasification. Catal. Sci. Technol. 2015, 5, 3658-3666. [CrossRef]

41. Grigorev, M.E.; Mikhailov, S.P.; Bykov, A.V.; Tiamina, I.Y.; Nikoshvili, L.Z.; Sulman, M.G.; Vasiliev, A.L.; Sidorov, A.I.; dos Santos, T.V.; Meneghetti, M.R.; et al. Surface interactions with the metal oxide surface control Ru nanoparticle formation and catalytic performance. Colloids Surf. A Physicochem. Eng. Asp. 2021, 610, 125722. [CrossRef]

42. Folkesson, B.; Bjorøy, M.; Pappas, J.; Skaarup, S.; Aaltonen, R.; Swahn, C.-G. ESCA Studies on the charge distribution in some dinitrogen complexes of Rhenium, Iridium, Ruthenium, and Osmium. Acta Chem. Scand. 1973, 27, 287-302. [CrossRef]

43. Shen, J.Y.; Adnot, A.; Kaliaguine, S. An ESCA study of the interaction of oxygen with the surface of ruthenium. Appl. Surf. Sci. 1991, 51, 47-60. [CrossRef]

44. Morgan, D.J. Resolving ruthenium: XPS studies of common ruthenium materials. Surf. Interface Anal. 2015, 47, 1072-1079. [CrossRef]

45. Auroux, A.; Gervasini, A. Microcalorimetric study of the acidity and basicity of metal oxide surfaces. J. Phys. Chem. 1990, 94, 6371-6379. [CrossRef]

46. Coşkuner Filiz, B.; Gnanakumar, E.S.; Martínez-Arias, A.; Gengler, R.; Rudolf, P.; Rothenberg, G.; Shiju, N.R. Highly selective hydrogenation of levulinic acid to $\gamma$-Valerolactone Over $\mathrm{Ru} / \mathrm{ZrO}_{2}$ Catalysts. Catal. Lett. 2017, 147, 1744-1753. [CrossRef]

47. Seretis, A.; Diamantopoulou, P.; Thanou, I.; Tzevelekidis, P.; Fakas, C.; Lilas, P.; Papadogianakis, G. Recent advances in Rutheniumcatalyzed hydrogenation reactions of renewable biomass-derived levulinic acid in aqueous media. Front. Chem. 2020, 8, 221. [CrossRef] 
48. Piskun, A.S.; van de Bovenkamp, H.H.; Rasrendra, C.B.; Winkelman, J.G.M.; Heeres, H.J. Kinetic modeling of levulinic acid hydrogenation to $\gamma$-valerolactone in water using a carbon supported Ru catalyst. Appl. Catal. A Gen. 2016, 525, 158-167. [CrossRef]

49. Galletti, A.M.R.; Antonetti, C.; De Luise, V.; Martinelli, M. A sustainable process for the production of $\gamma$-valerolactone by hydrogenation of biomass-derived levulinic acid. Green Chem. 2012, 14, 688-694. [CrossRef]

50. Chaparro-Garnica, J.; Navlani-García, M.; Salinas-Torres, D.; Morallón, E.; Cazorla-Amorós, D. Highly stable N-doped carbonsupported Pd-based catalysts prepared from biomass waste for $\mathrm{H}_{2}$ production from formic acid. ACS Sustain. Chem. Eng. 2020, 8 , 15030-15043. [CrossRef]

51. Linares-Solano, A.; Salinas-Martínez de Lecea, C.; Alcañiz-Monge, J.; Cazorla-Amorós, D. Further advances in the characterization of microporous carbons by physical adsorption of gases. TANSO 1998, 185, 316-325. [CrossRef]

52. Cazorla-Amorós, D.; Alcañiz-Monge, J.; Linares-Solano, A. Characterization of activated carbon fibers by $\mathrm{CO}_{2}$ adsorption. Langmuir 1996, 12, 2820-2824. [CrossRef]

53. Rodriguez-Reinoso, F.; Linares-Solano, A. Microporous Structure of Activated Carbons as Revealed by Adsorption Methods; Thrower, P.A., Ed.; Chemistry and Physics of Carbon: New York, NY, USA, 1989; Volume 21, pp. 2-146. ISBN 0-8247-7939-8.

54. Lillo-Ródenas, M.A.; Marco-Lozar, J.P.; Cazorla-Amorós, D.; Linares-Solano, A. Activated carbons prepared by pyrolysis of mixtures of carbon precursor/alkaline hydroxide. J. Anal. Appl. Pyrolysis 2007, 80, 166-174. [CrossRef]

55. Xiao, C.; Goh, T.W.; Qi, Z.; Goes, S.; Brashler, K.; Perez, C.; Huang, W. Conversion of levulinic acid to $\gamma$-valerolactone over few-layer graphene-supported ruthenium catalysts. ACS Catal. 2016, 6, 593-599. [CrossRef] 